\title{
HISTORICKÉ VĚDY
}

UDC 39(479)

DOI: $10.24045 / p p .2017 .1 .6$

\section{HISTORICAL-CULTURAL ASPECTS OF INVESTIGATION OF EVALUATION OF TEACHING EFFICACY PERCEPTION}

\author{
E. L. Hasanov
}

\author{
PhD., Senior specialist \\ Ganja branch of Azerbaijan National Academy \\ of Sciences \\ Ganja, Azerbaijan
}

\begin{abstract}
In this scientific article have been researched the basic features of investigation of evaluation of teaching efficacy perception on the basis of historical-cultural point of view. The aim of the present study is to determine how teaching efficacy is perceived by the faculty members working at the faculty of music. This study which examines faculty members' perception of teaching efficacy has a survey model design. Analyses have revealed that faculty members mostly regard themselves as efficient particularly in course design dimension. On the contrary, the dimension that makes faculty members feels the least efficient has been found to be learning assessment. Besides, significant differences were observed among faculty members' perception regarding teaching efficacy in terms of different variables such as gender, course match, training and seniority.
\end{abstract}

Keywords: education; history; teaching; efficacy; Azerbaijan.

\section{Introduction}

As a natural prerequisite of these principles, the following principles attach great importance not only to the studies concerning the value and impact of arts education but also to the well-trained teachers (1). As in the other branches of art, music also has a message and call to the minds through senses. The person who has not received music education fails in the transmission of music and artistic values due to the lack of mental activity [9, p. 41]. The development and level of art education will be determined by the quality of the education. In fact, this quality depends on welltrained teachers in terms of both the field of art and their teaching skills [8].

Music education is a field of study correlated with the acquisition of musical knowledge, skills, perceptiveness and habits which are required by a particular branch of the profession [2].
Thus, it is of paramount significance to raise individuals who have high self-esteem in order to keep up with the up-to-date world and who are expressive, productive, constructive and creative. Music also readies individuals for living wholesomely through helping to develop their basic mental skills and capacities. Teachers who update themselves with a great love for their profession will enrich the value of music in the development of individuals and communities.

All professions are required to have various qualifications. Self-efficacy sheds light on the understanding whether individuals have these skills or not. Bandura [1] defines self-efficacy as the one's belief in one's ability to accomplish to succeed in certain situations. As for Luszczynska et al. (2005), self efficacy refers to one's coping with the "hard and vague tasks as well as one's belief in one's competences for challenging with spe-

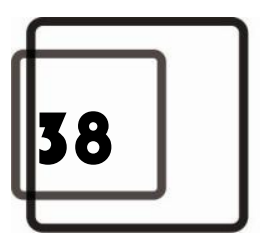


cial needs and the Perception of SelfEfficacy in Organizational Entrepreneurship. Music teachers should possess a good harmony of skills and content knowledge. Besides, they should be armed with the qualities, laws, theories, basic elements, the relationships between these elements and basic knowledge about the historical development of music. It is also essential that teachers recognize society and other cultures with their functions.

\section{Materials and methods}

Being one of the most specific features of the profession, teaching qualification is indispensable for music teachers. Music teachers are those who have such skills as planning, organizing, directing, executing, guiding and evaluating teaching-learning process concerning the didactic and methodical qualities for the purpose of transferring their knowledge and teaching skills effectively to the students [3-5].

As one of the requirements of teaching profession, music teachers should be equipped with specific skills and knowledge. In this regard, it is of highly significant for them to recognize school environment and its dependencies as well as current trends in the profession. Individuals with different abilities and characteristics vary across their learning styles and strategies. The regulation of teaching materials enriched with methods and techniques by taking into account the differences in the learning environment will improve student achievement [2]. Considering students' age and level, teachers nurture a pleasant learning environment through using appropriate techniques [3].

Music teacher is the one who is competent enough to enhance students' learning by implementing theory, sound and musical dimensions available in the curriculum into student behavior [6].

Online training system, which makes it possible to transmit video and audio messages between teacher and student on a reciprocal basis, is used in almost every field and at every level of music education. Countless online music sites are available on the internet concerning music theory, instrumental and vocal training. Moreover, there are some sites only for children, beginners and professionals while others provide an opportunity for students who are at elementary, intermediate and advanced levels to choose the appropriate program based upon their levels [2].

This study which examines faculty members' perception of teaching efficacy has a survey model design. The research used screening model that aims to describe events, objects, assets, organizations, groups, and various areas [8].

As for the faculty members' teaching efficacy perception depending upon their teaching experience, only the dimension of course design shows a significant difference. Five of the other dimensions are free from a significant difference.

\section{Conclusion}

This research has examined teaching efficacy perception of faculty members working at the department of music. Accordingly, course design has been determined as the highest efficacy dimension for faculty members. Technology usage, classroom management, instructional strategy, interpersonal relation and learning assessment are ranked in a descending order. In her study, Bedir (2015) indicates that the dimension that faculty members mostly feel competent is classroom management, which is followed by course design, interpersonal relation, learning assessment, technology usage and instructional strategy, respectively. Likewise, Chang et.al. (2011) also revealed that instructional strategy is the least efficient dimension for faculty members. Gelbal, Kelecioğlu (2007), Benzer\&Eldem (2012) report that teachers use traditional assessment methods and hence they do not have the required qualifications

Paradigmata poznóní. I . 20 I 7 
for using measurement techniques. On the other, Özdoğru and Çakır (2014) conclude that faculty members are competent enough to use technological materials. Ünal and Budak (2013) state that faculty members were unable to use equipment due to the lack of them in schools. Upon analyzing faculty members' perception concerning teaching efficacy with respect to gender, the difference is in favor of female faculty members in terms of all dimensions except for classroom management. As for the match between teachers' background education and the courses they teach, a significant difference was found in favor of those with a full match in terms of course design. Depending upon attending a training course about the profession, those who took part in training have higher levels of teaching efficacy perception across course design, instructional strategy and technology usage. With regard to the teaching efficacy perception of faculty members in terms of seniority, the dimension of course design refers to a significant difference in favor of those whose teaching experience is more.

The dimension that makes faculty members feels the least efficient has been found to be learning assessment. Thus, it is essential that courses organized for faculty members about the most suitable alternative assessment methods depending on their branches. Besides, organizing seminars on interpersonal communication and alternative teaching strategies also provides opportunities for fac- ulty members to improve themselves in this regard.

\section{Bibliography}

1. Bandura, A. (1995). Self-Efficacy in Changing Societies, Cambridge: Cambridge University Press.

2. Bedir, G. (2015). Perception of Teaching Efficacy by Primary and Secondary School Teachers. International Electronic Journal of Elementary Education, 8(1), 41

3. Bedir, G. (2011). Öğretim İlke ve Yöntemleri (Ed. Uzunboylu, H \& Öner, G). İstanbul: Lisans Yayıncılik.

4. Bedir, G. (2007). İlköğretim 4. ve 5. sınıf öğrencileri, öğretmenleri ve velilerinin öğrenme stili profillerinin değerlendirilmesi. Yayımlanmamış Doktora Tezi.

5. Benzer, A.,\& Eldem, E. (2012). Türkçe ve edebiyat öğretmenlerinin ölçme ve değerlendirme araçları hakkında bilgi düzeyleri, Kastamonu Eğitim Dergisi, 21(2), 649-664.

6. Can, M. Cihat, 2001, "Online Müzik Eitimi”, Çada Eitim, say1 276, s. 9-14, Ankara.

7. Chang, T., Lin, H., \& Song, M. (2011). University faculty members' of their teaching efficacy. Innovations in Education and teaching International Journal, 48 (1), 49-60.

8. Gelbal, S., \& Kelecioğlu, H. (2007). Öğretmenlerin ölçme ve değerlendirme yöntemleri hakkındaki yeterlik algıları ve karşılaştıkları sorunlar, Hacettepe Üniversitesi Eğitim Fakültesi Dergisi, 33, 135-140.

9. İpşiroğlu N., Sanattan Güncel Yaşama, Pan Yayıncılık, İstanbul, 1998.

10. Luszczynska, A., Scholz, U. \& Schwarzer, R. (2005). The General Self-Efficacy Scale: Multicultural Validation Studies. The Journal of Psychology, 139(5), 439-457.

(C) Hasanov E. L., 2017.

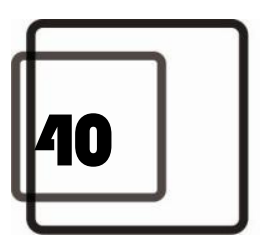

